\title{
Rapid urbanization and changing land values in mega cities: implications for housing development projects in Dhaka, Bangladesh
}

\author{
Md. Jahangir Alam*
}

*Correspondence:
jahangirsociology@gmail.
com
Department of Sociology,
University of Dhaka,
Dhaka 1000, Bangladesh

*Correspondence: jahangirsociology@gmail.

Department of Sociology, Dhaka 1000, Bangladesh

\begin{abstract}
This paper explores changing land values in the process of rapid urbanization in Dhaka, Bangladesh and its implications for urban land management and administration in the megacity. The study reveals that substantial increase in land values have resulted in land speculation among real estate and individual developers. Land values have increased by an average of 22.26\% per year between 1990 and 2000, while the period spanning from 2000 to 2010 saw about 74\% of yearly increase in Dhaka. The study revealed that due to increasing land values, prospective real estate developers are tempted to build housing in restricted areas defined by Dhaka metropolitan development plan such as flood zones, lakes, canals, ditch and drainage channels etc. The paper proposes a re-look at the causes of increase in land values and land speculations and the resulting environmental damage pointed out in this study as part of a broad urban land and environmental management strategy in rapidly growing megacities.
\end{abstract}

Keywords: Land value, Housing projects, Real estate developer, Dhaka, Bangladesh

\section{Background}

Urbanisation has become one of the greatest environmental challenges in the world today. Largely, the term urbanisation refers to the alteration of an agricultural economy to that of a manufacturing and service-oriented economy (Mandal 2000 cited in Dewan et al. 2012). Globally, a strong trend of urbanisation has been observed since 1900 (Dewan et al. 2012). Estimates show that only 10\% of the global population was living in urban areas in 1900. This grew to 30\% in 1950 and 47\% in 2000 (UN 2002). Projections are that by 2025 , the urban population will represent more than two-thirds of the world population, and the current rate of urbanisation is much higher in developing countries than in the developed world; predictions indicate that by 2020, most of the mega cities 1 of the world will exist in developing countries (World Bank 2007).

Increasing urbanization through peripheral land conversion is of global concern since urban expansion onto peripheral/rural lands significantly affects energy flows, biodiversity and climatic conditions at local and/or regional levels (McDonnell et al. 1997; Baker et al. 2001; Green and Baker 2003). Besides, urbanization causes vulnerability to natural hazards (Wenzel et al. 2007; Weng 2001), substantial reduction of cultivable lands (Lopez et al. 2001), habitat damage (Alphan 2003), species loss (McKinney 2006), the

(c) The Author(s) 2018. This article is distributed under the terms of the Creative Commons Attribution 4.0 International License (http://creativecommons.org/licenses/by/4.0/), which permits unrestricted use, distribution, and reproduction in any medium, provided you give appropriate credit to the original author(s) and the source, provide a link to the Creative Commons license, and indicate if changes were made. 
reduction of net primary productivity (Xian et al. 2007), and landscape change (Grimm et al. 2008; Herold et al. 2002). All these changes are identified as decisive factors attribute to global change (Nagendra et al. 2004), which would negatively impact the humans (Liu et al. 2003).

Rapid urbanization due to large scale land use change, particularly in developing countries becomes a matter of serious concern since urbanization drives environmental change at multiple scales (Dewan et al. 2012). As population concentration in urban areas is growing persistently across the world and putting tremendous pressure particularly on land resources, rich understanding on the history and processes of land use change can help plan for better land management and the reduction of impacts on the environment. Dhaka, the capital of Bangladesh, has been experienced break-neck urban growth through restricted area land filling in the last few decades that resulted many adverse impacts on the land markets and social and environmental arena. Where increasing value of land playing a pivotal role to rapid change.

A piece of land is now-a-days being treated as the prime asset to an individual or an institution all over the world. The owner of a piece of land in one of the prime locations of a megacity is considered as one among the richest people in the city. Finding a clean land to purchase is really a difficult task in developing cities, where efficient institutional land management is absent. Different studies show that land management is becoming increasingly difficult in many countries throughout the world. Koonings and Kruijt (2009) indicated that the urban land management and administration in Global South has been experiencing unclear regulation, plural ownership, (where same land has been sold several times to several people using fake documents) and conflicting or non-existing urban land policies. They have also pointed out that the presence of various groups, individuals, and other non-state actors are continuously shaping the politics of urban land ownership, administration, values and market dynamics. Alam (2011) found that this scenario is also omnipresent in the land scarce city of Dhaka. According to Dowall (1992), government regulations on land use and land development affect land and housing market in three broad ways: (i) land supply constraints, (ii) excessive plot-size standards and subdivision design, and (iii) procedural delays and red-tape.

At present, megacity Dhaka has been experiencing procedural delays and bureaucratic red-tapism in land registration, plan approval for land development, handing over of plots. Besides, urban management authority in Dhaka is encouraging high rise apartment development in the inner city against housing plot development in urban peripheral lands. Thus, government policy regarding urban land has significant implications on urban land market, particularly on residential land value. Despite of the existence of these problems, land price has been growing overwhelmingly in developing countries (Mayo 1998; Seraj 2007; Makathy 2008), particularly in megacity Dhaka (Seraj 2007). Therefore, it is necessary to study the trend of residential land price escalation and its consequences in cities of developing countries. Such a study would generate new information and data that would improve urban land planning and zoning and thus solve many urban environmental problems.

According to Alam (2011), sky-rocketing land values of the megacity Dhaka is the main reasons for sprawling peripheral land developments and indiscriminate fillings of lowlands. In this connection Einsweiler (1995), in his analysis of city sprawling 
emphasized that "urban growth boundary" will have to be enforced to varying degrees to ensure sustainable urban development, where urban land values, especially residential land values bear significant policy implication. Limiting growth boundary will heighten the land price to a greater degree inside the boundary, and to a lesser degree outside the boundary.

Begum (2007), pointed out that sprawling peripheral land developments and indiscriminate fillings of lowlands are results of severe urban land management problems. These problems are aggravated by the sky-rocketing land values of the megacity Dhaka. At present, Dhaka's land price is increasing at a tremendous rate which is much higher than the contemporary developed and developing cities in the world. Recent evidence (for the time span from year 2000 to 2010) from different studies (Makathy 2008; Seraj 2007; Mayo 1998) reveal that among cities of some neighboring South Asian countries, the average percentage increase in land value per year was the highest in Dhaka (74\%), followed by Karachi (70\%), and Kolkata and Kathmandu (50\% for both). The exorbitant inner-city land price increase in megacity Dhaka is one of the major contributory factors for developers' irregularities in project development, plot registration and plot handover (Alam 2011).

In such a context, it seems that the current trend of land development in Dhaka is more of a response to speculative motive of land developers than a response to growing housing needs. Sensing the booming real estate market in recent years, some foreign investors have already shown their keen interest for investing in Dhaka's land market. Developers' huge demand for land will put more pressure on DMDP restricted areas' land, such as flood flow zones, natural water bodies of lakes and canals. This would result in urban flood, water logging and environmental problems.

Therefore, the objective of the paper is to examine the increase in land values in megacity Dhaka over the years and depict the implications of the changes in land values on urban environment, residential development and housing market in megacities where most of the city inhabitants are middle or lower middle class people. This information virtually guides urban planners, ecologists, and resource managers to support sustainable development in rapidly changing regions (Herold et al. 2002).

\section{Study area and the methods of the study}

Dhaka generally means the central city that is the jurisdiction of $290 \mathrm{sq} . \mathrm{km}$ of Dhaka city corporation (DCC), including. The study was carried out on the Dhaka metropolitan development plan (DMDP) area of Rajdhani Unnayan Kartripakkha (RAJUK). ${ }^{1}$ The DMDP area sums to 1528, $390 \mathrm{sq}$. km. of Dhaka metropolitan police (DMP) area, and five municipality areas inside DMDP; namely, Narayanganj, Kadam Rasul, Gajipur, Tongi and Savar. Figure 1 shows the location of Dhaka and the study area with its boundary.

This study was a part of doctoral research by the author and the article is primarily based on the data and information collected for that research during January to April, 2008. The study uses both primary and secondary data for analyzing the urban land value of Dhaka. A mixed method was applied for this research comprising qualitative

\footnotetext{
${ }^{1}$ RAJUK (Rajdhani Unnayan Kartripakkha) the capital development authority is the regional planning organization responsible for planning, development and development control of $1528 \mathrm{sq} . \mathrm{km}$ area of Greater Dhaka.
} 


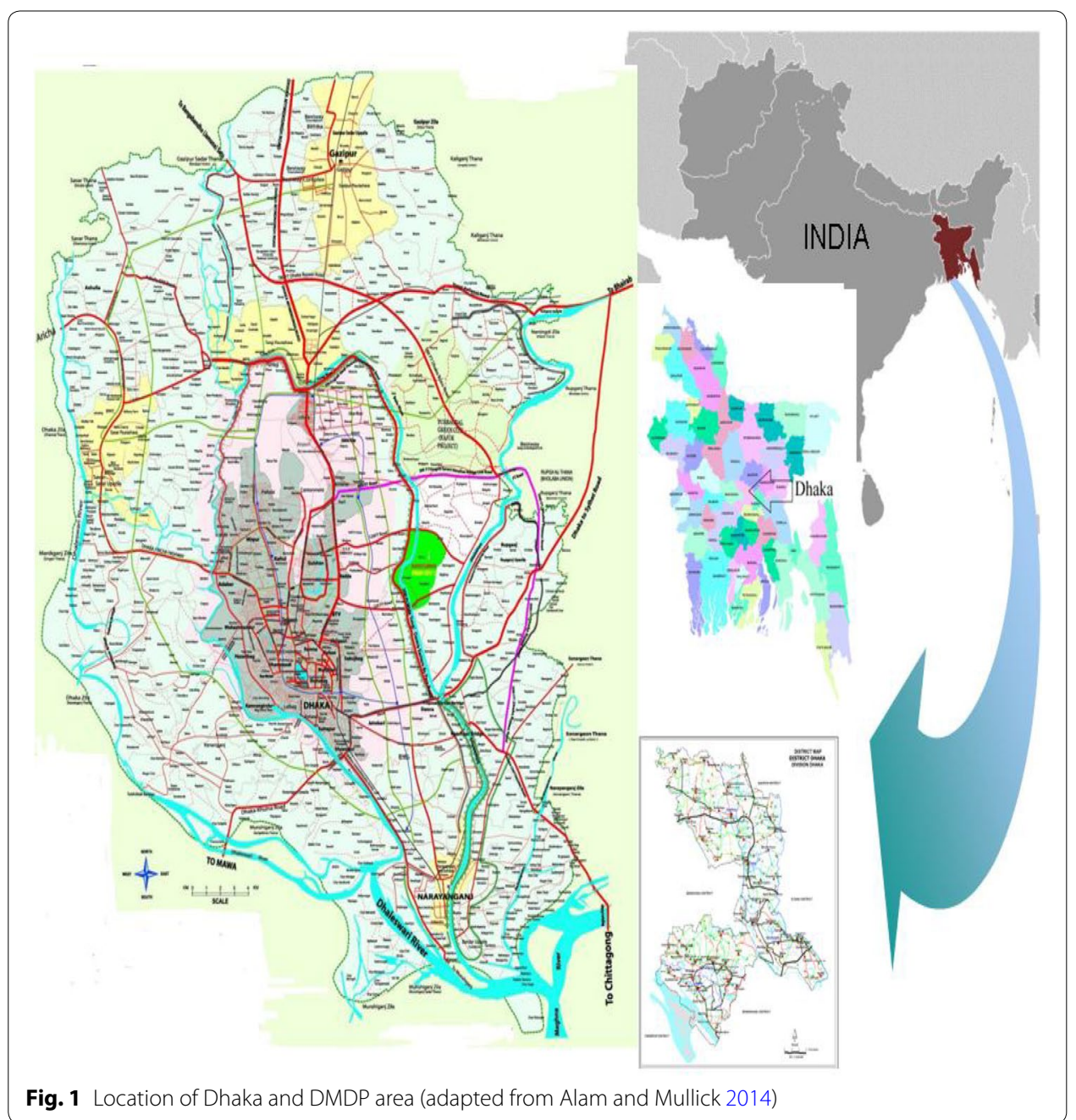

techniques for analyzing the data gathered from DMDP reports review, interviews, discussions and maps. Quantitative analysis was employed to interpret the data gathered until 2016 related to land value from primary and secondary sources.

In order to collect primary data on land value particularly for land and housing development projects, a field survey was conducted using both structured and semi-structured questionnaires with relevant authorities, developers, researchers and planners. Besides, questionnaire survey on 117 land owners affected by housing projects and 95 plot buyers from 04 public and 100 plot buyers of 11 private land and housing development projects in the jurisdiction area of RAJUK in Greater Dhaka was also conducted. Information regarding total number of plot buyers was collected from RAJUK for the public plot buyers and from the real estate housing association of Bangladesh (REHAB) and Bangladesh land developer association (BLDA) for private sector housing projects.

As of 2008, 18 approved housing projects were developed by the public sector and 33 approved projects were developed by the private sector in Dhaka, of which 15 were selected for the survey (29.41\% of the total projects). A reconnaissance survey was also conducted to physically observe the condition of the housing projects in the DMDP area. Based on the reconnaissance survey, four public and 11 privately developed projects 


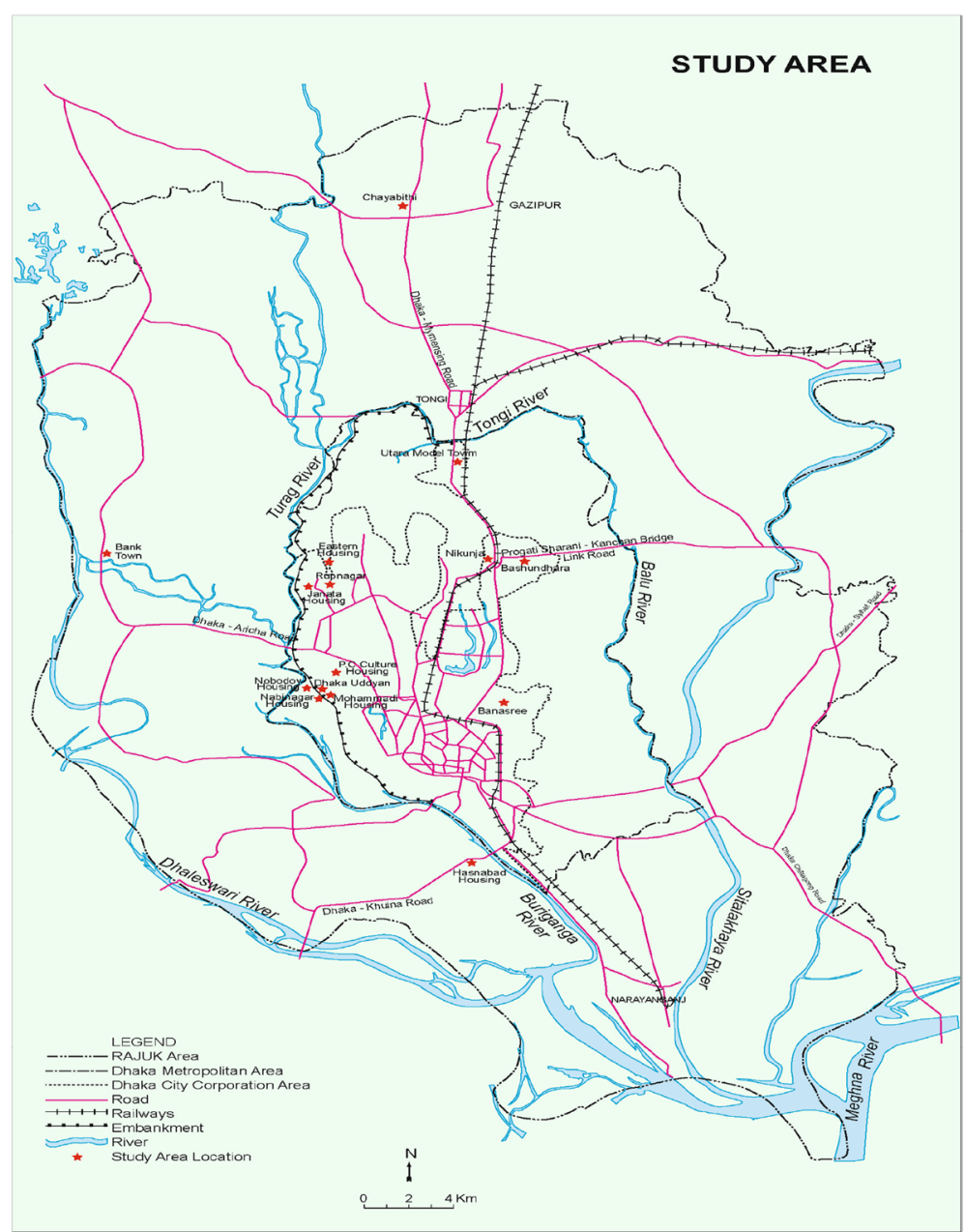

Fig. 2 Location of the housing projects in the study area (adapted from Alam and Ahmad 2013)

(shown in Fig. 2) were purposively selected for the study considering their similarities in terms of some characteristics. Similar plot size (0.02-0.03 ha) was considered for the project area from both public and private housing projects. The main features of these projects include: (a) locations (15-40 km away from city centre); (b) comparable plot size and expected similar condition of physical and environmental infrastructures; (c) similar socio-economic conditions of the inhabitants; and (d) project starting off during 1983-1990. The names of the public sector housing projects studied were: Uttara Model Town, Nikunja, Rupnagar housing, and Chayabithi housing. The private housing projects studied were: Basundhara Baridhara project, Janata housing, Hasnabad housing, Mohammadia housing, Banasree new town, Nobodoy housing, Nabinagar housing, Dhaka Uddyan, P.C. culture housing, Eastern housing Pallabi extension, and Bank town housing of Greater Dhaka.

The respondents for this research were selected randomly. Questionnaire survey was conducted among the residents who were owners of the plots and had been living in the project areas for a long period of time. About 30\% of the households in both project 
categories appeared to be relatively long-term residents (more than 10 years). Data were collected from available respondents of the households.

The views expressed by the authorities, developers, researchers and planners about the existing scenarios were also considered and incorporated in the analysis. It is to be clarified here that the phrases 'land price' and 'land value' have been used interchangeably in this study.

\section{Changing residential land values in Dhaka}

The area of Dhaka has been extended in different times through changes in the legal and/ or administrative status. RAJUK's area has been extended from $829 \mathrm{sq} . \mathrm{km}$ in 1959 to 1528 sq. km in 1990. The Dhaka metropolitan development plan 1995-2015 for Greater Dhaka ${ }^{2}$ has encouraged pace of land and housing development projects. But at the same time it has facilitated upsurge in land conversion for urban use and escalation in land values in the DMDP peripheral area. Dhaka, the capital of Bangladesh with the present annual population growth rate of around 4\% (CRDP, 2014), compared with an annual average of $1.37 \%$ for the overall country (BBS 2014) is the most densely populated city in the world with 43,500 people living per square kilometer (BBS and UNFPA 2016 cited in The Daily Prothom Alo 2016a). Moreover the megacity faces a daily influx of 1700 new population (The Daily Prothom Alo 2016b). This megacity is characterized by limited land supply against huge population for its geographical and physical constraints.

Primarily two types of land markets are available for residential land development in Dhaka: (a) public sector land developers-RAJUK and NHA (national housing authority) (b) private sector land developers under REHAB (real estate housing association of Bangladesh) and BLDA (Bangladesh land developer association). According to Chaudhury (1995), residential land values in Dhaka has increased more than thirty times during 1970-1980. Particularly, the land for housing in any available urban land in Dhaka has given rise to the soaring land prices during the last few decades and resulted in diminishing patches of empty lands within city limits. The unusual price increases had immensely facilitated the proliferation of land and housing development projects in periphery of Dhaka including the restricted areas (Fig. 4). The land price hike has also contributed to land speculations among buyers and developers. However, the prohibitive prices of land in Dhaka restrict the majority of population with low and middle income to have access to land markets.

\section{Dynamics of increasing land value in the megacity}

This subsection mainly discusses the changes in the prices of lands used for residential purpose in Dhaka. The changes in prices in prime locations, in all the different regions in Dhaka and in land and housing development projects have been studied here.

\section{Prime locations and regions}

Dhaka city has experienced an unprecedented increase in land price since 1970s. Comparison of land price data: (i) in prime locations and (ii) by regions in Dhaka are presented in Tables 1 and 2 respectively.

${ }^{2}(1$ Bigha $=20$ katha; 1 katha $=720$ sq. ft $)$. 
The data in Table 1 show that urban land price in Dhaka's prime locations have been increasing at an annual rate of 16.37-145.23\%, depending on the location. Gulshan, one of the residential areas of affluent citizens in Dhaka city (increasingly used for commercial purpose), has recorded the highest percentage increase in land price.

Over the decades land price in Dhaka city has increased excessively. However, in the urban fringe areas of Dhaka the annual change in land prices vary from $20 \%$ to nearly $130 \%$. Data show that (Table 2), in the time span of 35 years, the city residential areas of Baridhara, Gulshan, Dhanmondi and Uttara has registered higher percentage increase compared to the fringe areas of Savar, Demra, Gazipur and Keraniganj. Land price escalation in and around the city, on an average was more than 235\% per year from 1975 to 1990. The corresponding figures for the period $1990-2000$ was $22.73 \%$ and about $72 \%$ during 2000-2010.

Such phenomenal growth in land price has led to land speculation, particularly among real estate apartment and land developers and individual plot buyers. The exorbitant land price in Dhaka city area has pushed up the land price in urbanized fringe and peripheral areas of Greater Dhaka too. Consequently, the city is loosing its surrounding open spaces, lowlands, waterbodies and greenbelt. Data from the field survey shows that peripheral rural areas of Dhaka have also experienced price increases ranging from 60 to 96.7\% per year between the years 2000 and 2010 (Table 2).

\section{Land and housing development projects}

At present real estate business is the highest profit venture. Entrepreneurs with or without prior experiences are increasingly engaging themselves for grasping this profit. This is incessantly expanding the residential land transaction horizon.

According to the field survey, among 15 housing projects in Dhaka city, land in Eastern Housing Projects is most expensive, at roughly US $\$ 796.98 / \mathrm{m}^{2}$, followed by Nikunja and Bashundhara housing projects at US $\$ 538 / \mathrm{m}^{2}$ and Uttara Model Town at US $\$ 527 / \mathrm{m}^{2}$. Dhaka's land price is significantly higher than the land prices in cities of United States (whose per capita income is 20 times higher than Bangladesh), for example, Miami US $\$ 118 / \mathrm{m}^{2}$, Boston US $\$ 140 / \mathrm{m}^{2}$, New York US $\$ 344 / \mathrm{m}^{2}$ and San Francisco US $\$ 689 / \mathrm{m}^{2}$ (Glaeser and Gyorko 2003 cited in the World Bank 2007). Because of the booming real estate market some foreign investors have already shown a keen interest in investing in Dhaka's land market. This will put more pressure on Dhaka's land price.

Table 1 Land value in prime locations of Dhaka city. Source: modified from Kamruzzaman and Ogura (2008), cited in Chowdhury (2012), p. 153

\begin{tabular}{llrl}
\hline Location & \multicolumn{2}{l}{ Land price $\left(\right.$ Taka/ $\left.\mathbf{m}^{\mathbf{2}}\right)$} & Yearly increase (\%) in per $\mathbf{~}^{\mathbf{2}}$ of prime urban land \\
\cline { 2 - 3 } & $\mathbf{1 9 7 5}$ & $\mathbf{2 0 0 5}$ & \\
\hline Gulshan & 2398 & 106,891 & 145.23 \\
Dhanmondi & 2398 & 91,816 & 124.29 \\
Mohammadpur & 1713 & 37,686 & 70.00 \\
Shantinagar & 1918 & 37,686 & 62.16 \\
Mirpur & 960 & 22,954 & 16.37
\end{tabular}

1 US\$ = BDT. 78 


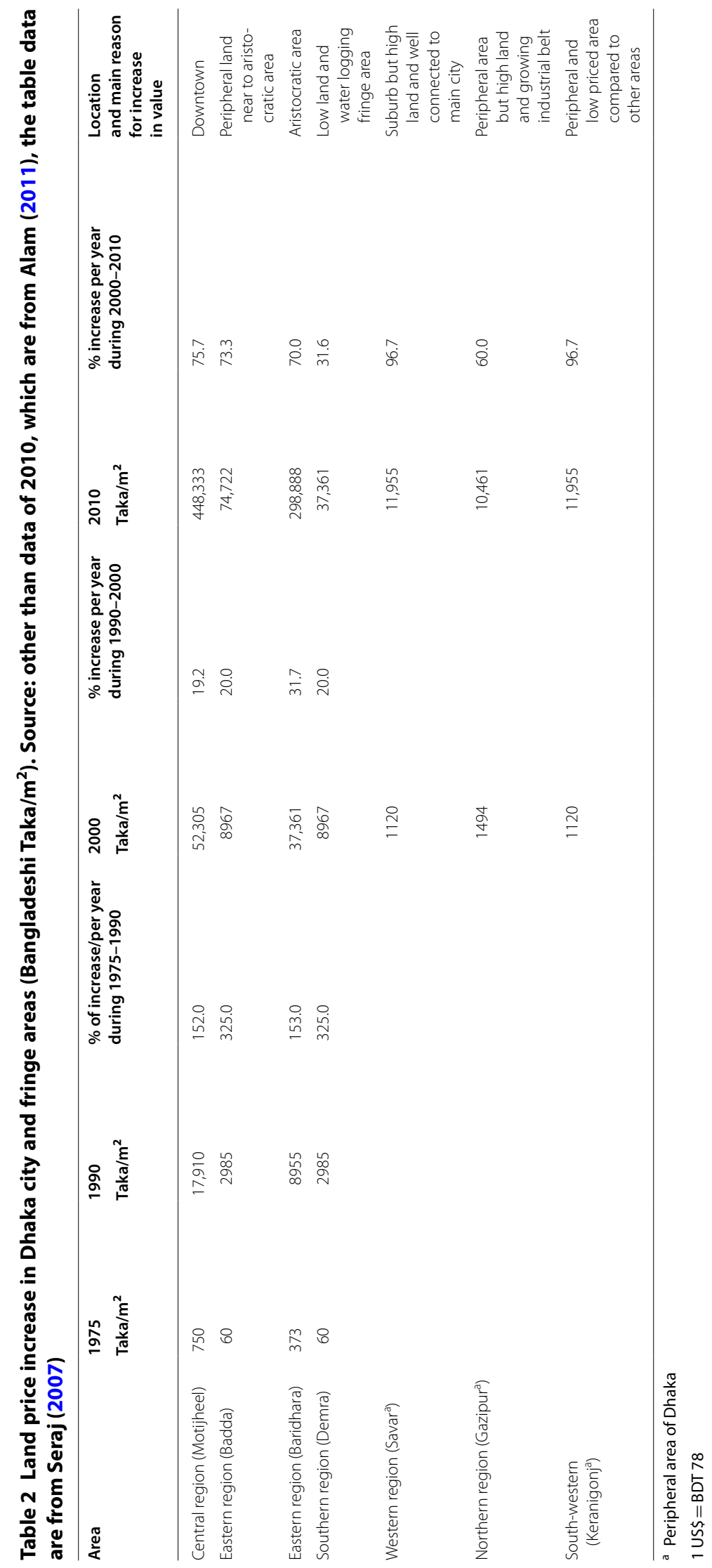


From a questionnaire survey conducted among 195 plot buyers, it is found that each plot has gained noteworthy increase in its price. During the period 1983-2008, market value of lands has increased by more than 5.8 times on average from its purchase price. Market value of lands in public housing projects has increased on an average by 5.3-fold ranging from 3.2-fold to 9.2-fold whereas, increase in market value of private housing projects ranges from 1.1-fold to 31.3-fold with an average of sixfold within the aforementioned time period (Table 3).

It can be noted that the average increase of market value of land in private housing projects would be lower than that of the public housing projects (3.5-fold compared to 5.3 -fold) if we exclude the outlying case of the Bank Town housing project (where present price is more than 31 times of the purchase price).

This steep upward trend in land prices has also tempted developers and individuals to invest money in the land market. Such a trend is encouraging the city's uncontrolled expansion by massive land filling activities of the real estate developers.

\section{Land price increasing trend and profit figure}

In the above situation, real estate companies compete fiercely among themselves. It is no surprise that land receives more than its fair share of attention from land speculators and developers. It is widely reported that a gainful nexus has developed between the land developers and the people who are supposed to regulate conversion of farm land to urban land. In this regard, the most well-known case is that of Bashundhara housing project. Located in the eastern fringe of the city, its "land-grabbing practices" have been adversely affecting the topography of the city's surroundings. The profiteering from these activities is evident in the land value increase in Bashundhara (see Table 4 and the accompanying figure).

The above data, obtained from the official documents of the east-west property development's Bashundhara housing project, show it has experienced increase in land price in the order of 1.5 times to 23 times during the period of 1988-2006 (Table 4). It is to be noted that maximum interest rate in the formal financial system is $12.5 \%$, whereas the gain from investment in land ranges in the order of $150-2300 \%$ or 1.5 times to 23.0 times. Thus, it is no surprise that investment in land and land speculation is one of the highest profiteering sectors in contemporary Bangladesh.

\section{Drivers of land value increase in Dhaka}

According to UN-Habitat (2008/2009), there have been three very important drivers of urban growth in Dhaka: (i) economic and industrial policies, where the Bangladesh industrial policy of 1999 increased economic activities that encouraged three export oriented industries-ready-made garments, food processing and pharmaceuticals-as well as establishment of two economic zones (Savar and Dhaka export processing zones) and the Gazipur industrial belt in Greater Dhaka, (ii) improvements in quality of life, with increased proximity to high-quality schools, hospitals, markets and administrative services, which promoted housing projects on surrounding low-/wetlands, and (iii) changes in legal and/or administrative status, where the RAJUK area has been extended from $829 \mathrm{~km}^{2}$ in $1959-1528 \mathrm{~km}^{2}$ in 1990, and when DMDP 1995-2015 was prepared, the 
Table 3 Housing projects' land value increased in Dhaka (1983-2008). Source: Field Survey 2008

\begin{tabular}{|c|c|c|c|}
\hline \multirow[t]{2}{*}{ Name of the housing project } & \multicolumn{3}{|c|}{ Land price increase } \\
\hline & $\begin{array}{l}\text { Purchase value } \\
\text { (land price } / \mathrm{m}^{2} \text { ) }\end{array}$ & $\begin{array}{l}\text { Present value (land } \\
\text { price } / \mathrm{m}^{2} \text { ) }\end{array}$ & $\begin{array}{l}\text { Percentage increase/ } \\
\mathrm{m}^{2}\end{array}$ \\
\hline \multicolumn{4}{|l|}{ Public } \\
\hline Uttara Model Town & 6268.39 & $36,193.94$ & 477.40 \\
\hline Nikunja & 3636.45 & $36,979.2$ & 916.90 \\
\hline Rupnagar housing & 5297.62 & $27,368.42$ & 416.62 \\
\hline Chayabithi & 2156.35 & 9091.2 & 321.60 \\
\hline \multicolumn{4}{|l|}{ Private } \\
\hline Basundhara & 7792.54 & $36,779.23$ & 371.98 \\
\hline Janata housing & 6181.82 & $13,333.34$ & 115.69 \\
\hline Hasnabad Housing & 3636.36 & $11,636.35$ & 220.0 \\
\hline Mohammadia housing & 4116.6 & $27,272.98$ & 562.51 \\
\hline Banasree new town & 5479.58 & $18,812.90$ & 243.32 \\
\hline Nobodoy housing & 4349.09 & 16,000 & 267.89 \\
\hline Nabinagar Housing & 3369.70 & $12,848.50$ & 281.3 \\
\hline Dhaka Uddayan & 3083.64 & $10,181.81$ & 230.19 \\
\hline PC culture housing & 4480 & $29,963.41$ & 568.83 \\
\hline Eastern housing Pallabi exten. & 7786.82 & 54,400 & 598.62 \\
\hline Bank town & 398.54 & $12,872.74$ & 3129.94 \\
\hline
\end{tabular}

megacity underwent urban expansion, encouraged by housing projects in the surrounding flood flow zones (FFZ) and tremendous land values increase.

Dewan et al. (2010) found significant increase in urban land use and also observed very high degree of positive pair-wise correlation $\left(R^{2} \geq 0.9\right)$ between land use in Dhaka and some socio-economic, environmental and geographic factors. Their study supports the above mentioned findings of UN-Habitat and identifies Dhaka's industrial growth, increased overall economic activities (GDP), and population growth triggered by ruralurban migration as the major driving forces for increased land demand in Dhaka.

It can be deduced from the above arguments that increase in urban growth and land use in Dhaka originates from the increased demand for land which is governed by various reasons. And such increase in land demand put an upward pressure on the price of all types of land in Dhaka: residential and non-residential.

\section{Growing demand for residential apartments}

Construction of residential apartments amplifies the demand for land plots. Private real estate developers selling residential apartments emerged as potential housing providers in Bangladesh especially in Dhaka back in early $80 \mathrm{~s}$. At the beginning, there were less than 10 developers. The demand for land for apartment housing increased gradually as more and more developers came into the market. In 2000, there were about 200 companies in this sector. Now in 2014, the total number of real estate companies is more than 1500 (REHAB 2014). Figure 3 shows the contribution of real estate developers in housing sector from 1982 to 2013. Seraj (cited in CRDP 2014) shows that in recent years, the private sector constructed about 25,000 housing units per year of which more than 17,000 units were supplied by real estate developers (Fig. 3). Thus the building boom 
Table 4 Increase in land value in Bashundhara housing projects, 1989-2006. Source: revised from Alam and Ahmad (2010, p. 99), based on east west property development 2008 records

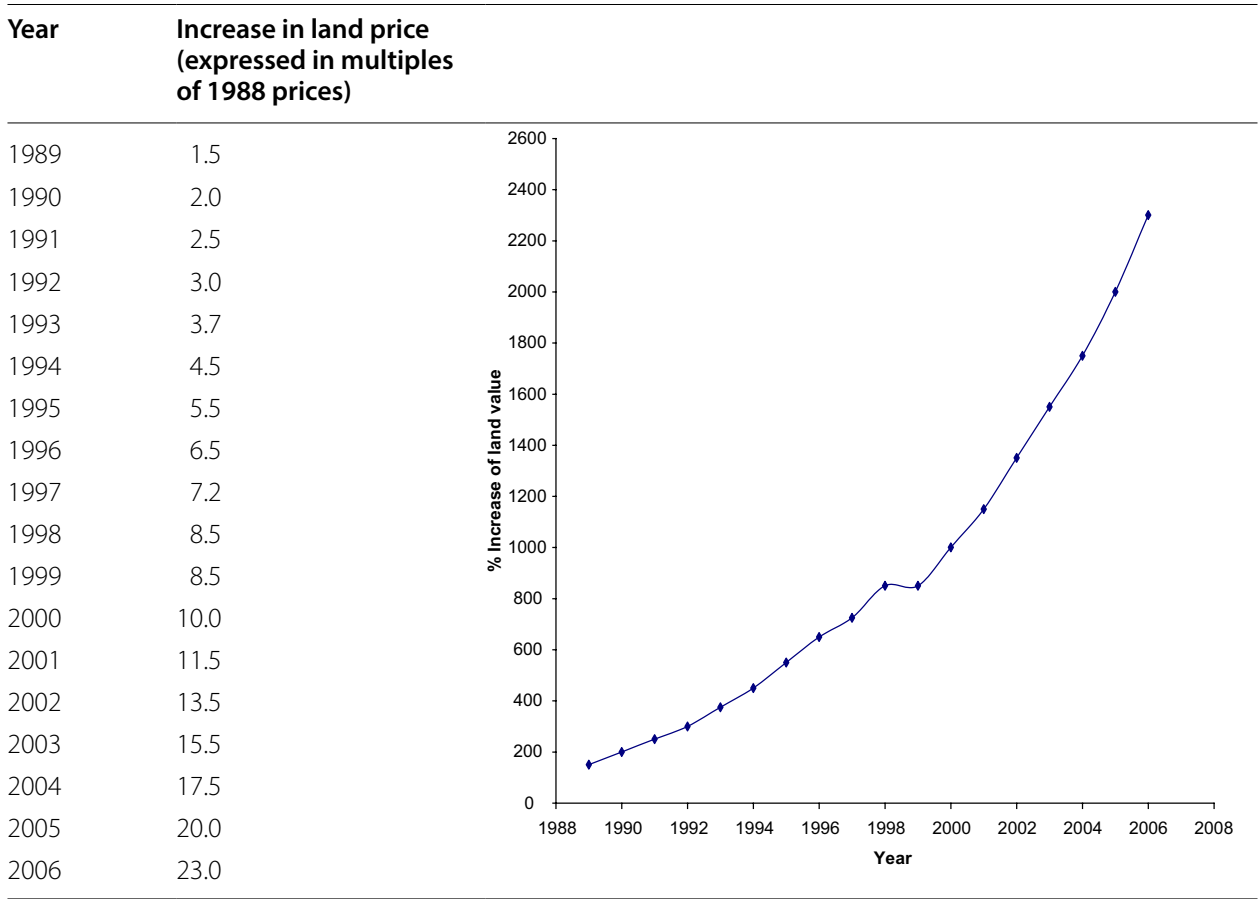

of residential apartments is another reason for increasing land values in Dhaka's land market.

Absence of ceiling of land holding policy

There has been a policy statement on the ownership of rural land in Bangladesh since the early 1950s. The 1984 Land Reforms Ordinance set maximum land ownership per person at 100 bighas $^{2}$ instead of 60 bighas. For the urban areas, no such ceiling of land ownership was defined except in the report of 1982 land reforms committee. The recommended ceiling was at only 5 kathas of land for the four metropolitan cities of Dhaka, Chittagong, Rajshahi and Khulna and at 10 kathas for other cities and towns. However, no practical measure was taken to implement this recommendation and the 1984 Land Reforms Ordinance does not make any mention of urban land ceiling. RAJUK has a policy of not allotting any plot to individuals already owning one in RAJUK area. Plot allotment is also restricted to individuals whose parents own a RAJUK plot. But violations of this policy is a common knowledge. The field survey revealed that $23.2 \%$ of public and $19 \%$ of private sector housing projects' plot owners of DMDP area own more than one plot.

It is important to note that the number of real estate land and housing project developers has increased greatly over the period of 1983-2005 (Alam 2011). These developers are in intense competition with each other to buy from individual land owners located in Greater Dhaka peripheral areas as limited stock of useable land in Dhaka. Each developer try purchase the land by paying higher price than his competitor to the private land owner. This is one of the contributing factors that fuel soaring land prices. For example, 


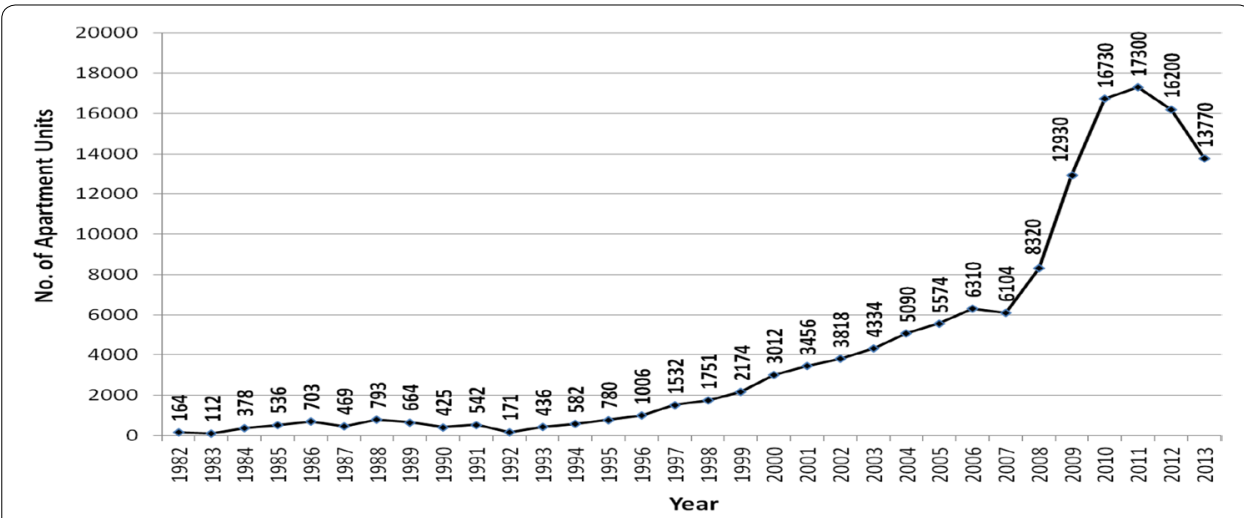

Fig. 3 Contribution of real estate developers in housing sector from 1982-2013 (Source: Seraj 2014 cited in CRDP 2014)

most of the peripheral lands have been rapidly purchased by private real estate developers for land and housing development projects, specially speculating on future price increases.

Again, Gafur (2008) reports that $95 \%$ of the business in the real estate sector is controlled by only ten companies. This means, in economic terms, that the market structure of the real estate industry is imperfectly competitive. This extends another explanation for increasing land prices. For, such market structure enables the real estate companies to set land prices at higher than efficient levels.

\section{Black money and foreign remittances}

Black money holders and foreign remittance earners are the principal buyers in land market. A third of investment from foreign remittances (World Bank 1981; p. 28, cited by Chowdhury 1992) and 20-25\% black money is also invested in this sector (Chowdhury 1992). They are cumulatively increasing land values and a class of few pocketing the gains. Presently Dhaka's land market is controlled by these factors and resultant situation is faster urban expansion in ecologically critical areas by massive land filling.

\section{Lack of investment opportunities}

People in the megacity Dhaka see investment in land as a secure and high profit from land value increases. Data shows that escalation in demand for apartments and land plots in the last 15-20 years has been the principal causal factor for land value increase. However, there are number of other reason for increasing land value in Dhaka City. Firstly; given the lack of productive investment opportunities with higher returns, the urban rich and high income Bangladeshi find investment in land most protected and profitable. Secondly; the market structure of the real estate industry is imperfectly competitive which extends yet another explanation why the real estate sector sets land prices at higher than efficient levels.

\section{Lack of inter-agency coordination and corruption}

Efficient urban management is particularly dependent upon good governance while developing cities are the manifestation of poor governance. Many recent studies have 
revealed that corruption in Bangladesh has severely constrained the development of the country's economy and inhibited the prospects of good governance (Rahaman 2008; Rahman and Khan 2008). Alam (2011) pointed out that both private and public developers violate DMDP polices. And absence of essential components of good governance has been identified as the main reason for low levels of compliance to DMDP plan. Important among other factors are corruption, strong political interference and lack of coordination among the urban management agencies. In Bangladesh the problems of inter-agency coordination in urban region take place due to lack of institutionalized rules and regulations and intricate bureaucratic management (Panday 2007).

Corruption in the many forms of bribe transaction is a fixture of daily life in Bangladesh (Knox 2009). Corruption in RAJUK and the abuse of rules and regulations play a large role in rapid unplanned city development in the megacity Dhaka (Alam and Ahmad 2013). Large numbers of housing projects, some even without formal approval, are mushrooming with high land value in Greater Dhaka under the illegal patronage of RAJUK officials. Thus RAJUK is being known as a centre of corruption serving the interest of rich and powerful (Islam 2001).

\section{Implications of increasing land values and growing housing development}

At present there are a number of laws to guide and control the land development of the DMDP area. Dhaka metropolitan development plan was prepared in 1995. MOST This plan is a combination of three plans; (a) the structure plan (1995-2015); (b) the urban area plan (1995-2005) and (c) the detailed area plan (1995-2015). The first two plans were finalized in 1997. It took RAJUK a very long time (until 2011) to finalize DAP which could not be executed due to serious objections from different stakeholders of the city; such as civil society, urban planners' association etc. Preparation of a new regional development plan (RDP) for RAJUK area for the period 2016-2035 has started in 2016 but it is still under review process. Consequently, demarcation and gazette notification of flood zone, retention ponds and agricultural land on mouza map are yet to be specified. Therefore, it is evident that the urban expansion through land and housing development that the megacity has experienced since mid ' 90 s has been completely unplanned as there was no clear plan to follow. Land constraints and scope speculation are encouraging developers for increasing land transaction in all types of areas including restricted zones.

\section{Land constraints and land speculations}

Land constraints and land speculation both have put pressure on urban expansion through peripheral low-land conversion. Land constraints with an ever-increasing demand are considered to be the most critical issue for urban expansion in Dhaka. It is learnt from the informal discussion with the local people, although most of the lowlying areas are still cultivated by farmers, there is a trend for them to sell off their land for high price and move elsewhere. Most of these lands are bought by individuals and housing companies, who buy the land for urban use and to achieve a higher price from future sale. Real estate companies compete with each other for fringe land, which leads to price escalation and land speculation. There is no regulation of land slaes in Dhaka city for developers and speculative plot buyers. It is no doubt that land receives more 
than its fair share of speculators. The cumulative effects of land price increases are widespread speculation and a large amount of peripheral land conversion (Alam and Ahmad 2010). Hence, low price fringe flood zones and agricultural lands in Dhaka are being rapidly purchased by private developers for housing projects, especially for speculating on a future price increase in the absence land ceiling provisions and price control mechanism.

Intensive speculation therefore stands as the second most critical issue, after extreme land constraints, which has pushed the development of housing projects to fringe lowlands and agricultural lands (Fig. 4). The neo rich and real estate business entrepreneurs, black money traders, foreign remittances (World Bank 1981 cited in Chowdhury 1992) and $20-25 \%$ of black money is also invested in this sector (Chowdhury 1992). At present, Dhaka's land market is controlled by these factors and the implication is more rapid urban expansion in ecologically critical areas.

\section{Loss of restricted and ecologically critical areas}

Profit maximization from increasing land value leads to environmentally critical area loss. Flood flow zones (FFZ), high value agricultural land and retention ponds are defined as the restricted areas in Dhaka metropolitan development plan (DMDP) (shown in Fig. 4). In order to protect Greater Dhaka from flooding and associated damages, the Dhaka metropolitan development plan (DMDP) demarcated the flood zone into two broad categories based on the two flow directions of the rivers adjoining the city.

One flow direction involves main flood flow zones (MFFZ) and sub-flood flow zones (SFFZ) of three rivers (Dhaleswari, Buriganga and Bangshi Turag) and the other flow direction involves the same of two rivers (Sitalakhya and Balu). As stipulated in the flood flow zone policy, any land or structural development within the flood prone areas as designated by the DMDP, will be controlled in order to avoid adverse hydrological effects such as rising of flood water levels and changing of the flow direction. Nonetheless, the high value and high demand for housing units in Dhaka has resulted in the development of more than 300 housing projects in restricted areas (Alam 2011; Alam and Ahmad 2013). At present, public developers like RAJUK and national housing authority (NHA) are also filling the existing retention ponds of the main city violating the DMDP law. Table 5 describes land conversion and filling of water bodies by public developers and also shows which acts/policies on retention pond filling the developers are violating.

Part of these retention ponds of Dhaka is meant for a $260 \mathrm{~km}$ drainage system, but presently the system is only $160 \mathrm{~km}$ (The Daily Prothom Alo 2008). Moreover, there are 250 canals and lakes around Dhaka, which are well interconnected with the surrounding rivers and wetlands that facilitate the flow of flood waters through such channels into the main rivers, wetlands, and low-lying areas. However, at the beginning of the 1990s, these low-lying areas or wetlands, lakes, khals (ephemeral water bodies), and drainage channels had been the main target of property developers. In 2005, the Dhaka water and sewerage authority (DWASA) identified 45 khals (The Daily Prothom Alo 2008) of which at present there are only 35 khals left (The Daily Sangram 2008). Moreover, all these 35 khals have been grabbed fully or partially, leaving the city drainage in a poor condition (The New Age 2017). Previously the width of these khals was $150 \mathrm{ft}$ but the continuous encroachment by different quarters of the population and developers had narrowed 


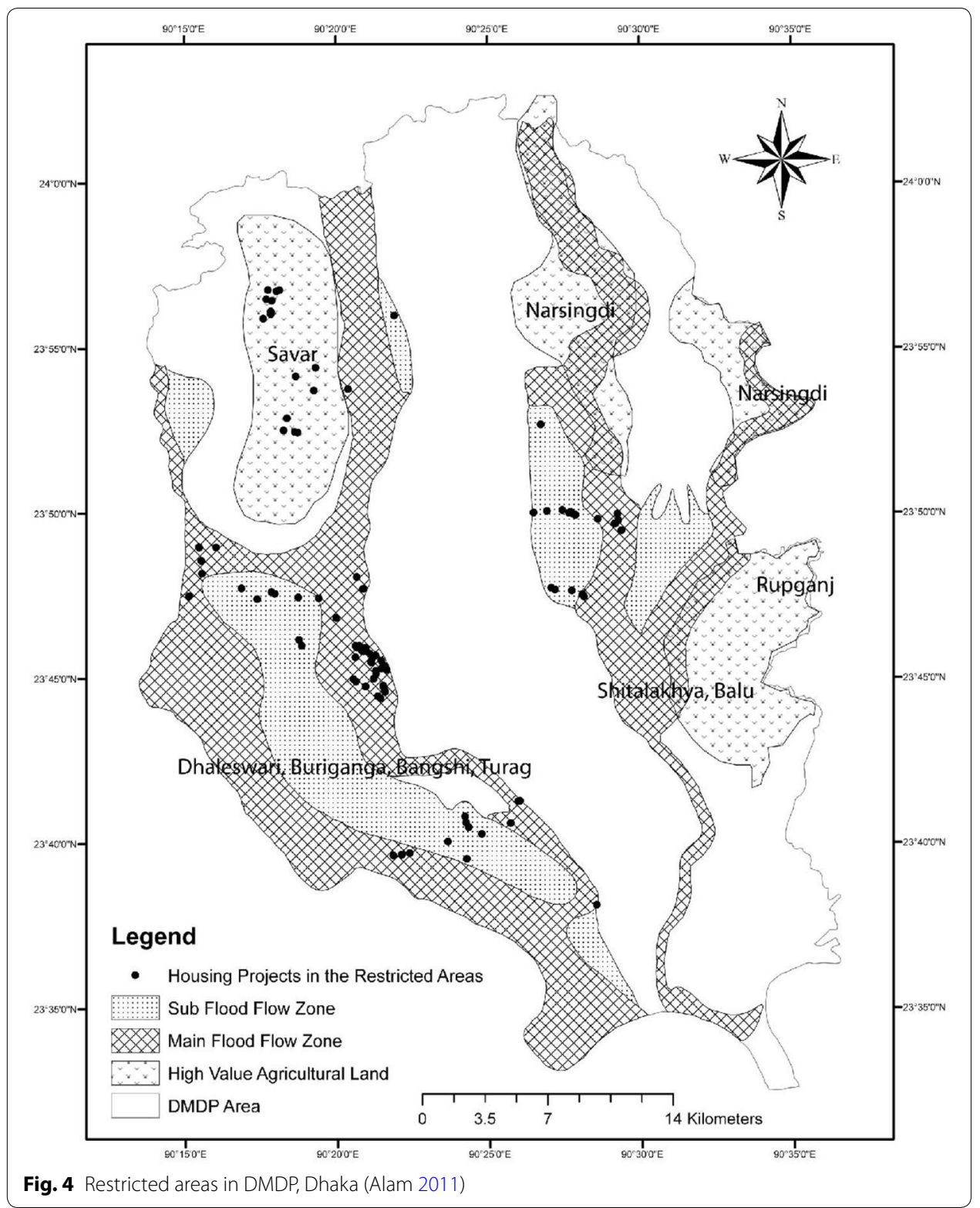

down the width to only $15-10 \mathrm{ft}$. As a result, Dhaka city faces sever water logging and drainage congestion with simply $10 \mathrm{~mm}$ rainfall, which consequently give rise to flooding in urban Dhaka.

Experts opined that during key informant discussion Dhaka will lose its four major tributary rivers in near future as a result of the way land and housing development projects are encroaching the environmentally critical water bodies along with other development activities. Rapid urban expansion in ecologically critical areas of Dhaka has been an outcome of encroachment of almost all the major lakes of the city by public, private and individual developers altogether. These encroachments also have broken the interconnectivity of the lakes and canals to the surrounding rivers. Thus water logging and flooding have become a major problem. Moreover, excessive land filling has increased 
Table 5 Land filling in restricted areas by public developers. Source: Field visit (2008); modified from Alam (2014) and The Daily Sangbad (2009)

\begin{tabular}{|c|c|c|c|}
\hline $\begin{array}{l}\text { Land/housing } \\
\text { development project }\end{array}$ & $\begin{array}{l}\text { Number of developed } \\
\text { plots/apartments }\end{array}$ & $\begin{array}{l}\text { Land conversion/water } \\
\text { body filling }\end{array}$ & Acts/policies violated \\
\hline $\begin{array}{l}\text { Purbachal new town of } \\
\text { RAJUK }\end{array}$ & 21,780 plots & $\begin{array}{l}2490 \text { ha of FFZ and high } \\
\text { value agricultural land } \\
\text { converted to housing } \\
\text { projects }\end{array}$ & \multirow{5}{*}{$\begin{array}{l}\text { Water body preserva- } \\
\text { tion Act } 2000 \text { which } \\
\text { declares lakes as } \\
\text { environmentally critical } \\
\text { areas FFZ, agricultural } \\
\text { land and retention } \\
\text { pond policies of DMDP }\end{array}$} \\
\hline Jhilmil project of RAJUK & 1800 plots & $\begin{array}{l}154 \text { ha of FFZ and High } \\
\text { Value Agricultural land } \\
\text { converted to housing } \\
\text { projects }\end{array}$ & \\
\hline $\begin{array}{l}\text { RAJUK Uttara Model Town } \\
3^{\text {rd }} \text { phase }\end{array}$ & 150 plots & $\begin{array}{l}\text { Filling up of } 300 \mathrm{ft} \text { wide } \\
\text { lake }\end{array}$ & \\
\hline $\begin{array}{l}\text { RAJUK Gulshan-Banani- } \\
\text { Baridhara project }\end{array}$ & 400 plots & $\begin{array}{l}\text { Filling up of Gulshan- } \\
\text { Banani lake which } \\
\text { narrowed down the lake } \\
\text { from } 500 \mathrm{ft} \text { to } 80 \mathrm{ft}\end{array}$ & \\
\hline NHA apartment project & 3360 apartments & $\begin{array}{l}18 \text { ha of Banani-Mohakhali } \\
\text { lake filled up }\end{array}$ & \\
\hline
\end{tabular}

earthquake vulnerability, because a major part of Dhaka's recent housing projects has taken place in landfilled sites (Kamal and Midorikawa 2004), particularly for loose areas.

\section{Loss of livelihood}

Housing project developments seeking profits from high land value in Dhaka are also accompanied by problems like farming and other environmental vulnerability. In southern Dhaka, land filling has added to soil pollution, resulting in reduced vegetation (Khatun and Hoque 1994). Questionnaire survey on affected people revealed a number of problems affected people face due to housing project development. The most significant problem was reported as the loss of agriculture (57.1\%). The other losses have been mentioned as loss of fishing (24\%), vegetation (17.7\%) and livestock (16.2\%). Besides, 50.87\% of the affected people also noted flooding problems, whereas $34.9 \%$ said that they suffer water logging because of the high level of land filling. Furthermore, the survey found that the large decline in cultivable land compelled $4.5 \%$ of affected local peoples to become day laborers in the urban built-up area.

\section{Loss in national output}

Again, out of the large number of housing projects developed in DMDP area only a few have all necessary services for living. Consequently, the vast land remaining vacant for 10-20 years have turned to a land locked area resulting in zero productivity for long time, which certainly is bringing economic loss to the country.

\section{Exclusion of the low and middle income class from land market}

The cumulative effects of land value increases are wide spread speculation and a large amount of peripheral land conversion. The low-priced, mostly fringe flood zones and high value agricultural lands in Dhaka are being rapidly purchased by private developers 
for housing projects (Fig. 4), expecting future price increase. But high land values have naturally excluded middle class ${ }^{3}$ and poor people from the urban land market. Both use and ownership of urban land in Dhaka show evidence of skewed distribution. It is evident from the study that about $57 \%$ of Dhaka's population owns no land in Dhaka whereas $4 \%$ of the population owns as much as $28 \%$ of land in Dhaka (MacAuslan 1999, p. 38). Equally revealing information is that $2 \%$ of Dhaka's population-the upper income group-use about $15 \%$ of the land; about $28 \%$-largely from middle income groupoccupy about $65 \%$ of the land and the remaining $70 \%$-who are mainly the urban poorhave access to only about $20 \%$ of the land. This huge land transaction's profit is going to the hand of few land and housing development project developers, black money traders, senders/receivers of foreign remittances and private sector professionals are among the bidders.

Therefore, speculating high profit from high land value encouraged developers as well as individual buyers to grab high productivity farm land, flood zones, lakes and canals. This results in withering away of rivers, lakes, canals, ponds and ditches from megacity Dhaka which ultimately intensifies the level of inundation the inner city during the wet season. Moreover, excessive land filling and land developments have many other adverse ecological, social and economic impacts as well.

\section{Conclusions}

Finally, since demand for housing in Dhaka is still on the rise and the government has not been responding thus far in the supply side, the formulation of incongruous laws and inconsiderate act of powerful developers' could only push the city dwellers face the flood damage and exorbitant price escalation. As a result, the inhabitants of Dhaka has been experiencing urban-environmental damage due to ineffective and weak governance and complicated policy making process. It is evident that the violation of DMDP policy by both public and private developers are continuous and suitably they are revising the master plan for their benefit. Therefore, developer's illegal lowland conversion and the presence of land speculation, which has a direct relation to its damages on the environment and livelihood of the suburb areas that makes the misappropriation of fringe flood flow zones and high value agricultural land possible. Consequently, rapid urban expansion through informality in the megacity resulting natural hazards of flooding, water logging in the inner city each year and lakes and canals filling, loss of forests, illegal land grabbing and low land filling in urban periphery.

\section{Authors' contributions}

MJA carried out the study durinng 2008 and further improved the article in 2016 with the latest relevant data. The author read and approved the final manuscript.

\section{Acknowledgements}

The present study was part of doctoral research by the author conducted at RRDP, AIT, Thailand in 2006-2011, with financial support from the University of Dhaka, Bangladesh, and AIT. The author gratefully acknowledges the financial supports to carry out the study. The author also wholeheartedly acknowledges Taslima Rahman's contribution for reviewing the paper and its'substantial editing.

\section{Competing interests}

The author declares that there is no competing interests.

Availability of data and materials

Not applicable.

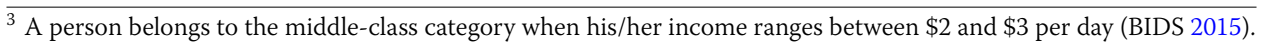




\section{Consent for publication}

I hereby give my consent for publication this article.

\section{Ethics approval and consent to participate}

Not applicable.

\section{Funding}

Not applicable

\section{Publisher's Note}

Springer Nature remains neutral with regard to jurisdictional claims in published maps and institutional affiliations.

Received: 9 June 2017 Accepted: 7 April 2018

Published online: 17 April 2018

\section{References}

Alam, M.J. 2011. "Land and Housing Development Projects and Ensuing Externalities in the Built-Environment: a Study in Dhaka, Bangladesh", Unpublished Ph.D. Dissertation. Bangkok: Asian Institute of Technology.

Alam, M.J. 2014. "The Organized Encroachment of Land Developers"—Effects on Urban Flood Management in Greater Dhaka, Bangladesh. Sustainable Cities and Society 10: 49-58.

Alam, M.J., and M.M. Ahmad. 2010. Analysing the Lacunae in Planning and Implementation: Spatial Development of Dhaka City and its Impacts Upon the Built Environment. International Journal of Urban Sustainable Development 2 (1-2): 85-106.

Alam, M.J., and M.M. Ahmad. 2013. Public Facilities in Public and Private Housing Projects, Dhaka, Bangladesh. Urban Policy and Research 31 (2): 190-207.

Alam, M.J., and R.A. Mullick. 2014. Climate Change Effects Upon Massive Land and Housing Development: Case of Dhaka, Bangladesh. International Journal of Climate Change Strategies and Management 6 (3): 315-331.

Alphan, H. 2003. Land Use Change and Urbanization in Adana, Turkey. Land Degradation and Development 14 (6): $575-586$.

Baker, L.A., D. Hope, Y. Xu, J. Edmonds, and L. Lauver. 2001. Nitrogen Balance for the Central Arizona-Phoenix (CAP) Ecosystems. Ecosystems 4 (6): 582-602.

BBS. 2014. Bangladesh Statistical Year Book. Dhaka: Bangladesh Bureau of Statistics.

Begum, A. 2007. Urban Housing as an Issue of Redistribution Through Planning? The Case of Dhaka City. Social Policy and Administration 41 (4): 410-418.

Chaudhury, Khasruzzaman. 1995. Urban Residential Land Values: The Case of Bangladesh City. The Bangladesh Development Studies 23 (1 \& 2): 105-125.

Chowdhury, A.I. 1992. Urban Land Market in Bangladesh. In Urban Land Management in Bangladesh, ed. Nazrul Islam, and Amirul Islam Chowdhury, 115-122. Dhaka: Ministry of Land, Government of Bangladesh.

Chowdhury, L.A. 2012. Quality of Urban Life: Service Realities. In Bangladesh Urban Dynamics, ed. H.Z. Rahman, 143-176. Dhaka: PPRC.

CRDP. 2014. City Region Development Planning Project (CRDP) Draft Report, Preparation of Revised Structure Plan for RAJUK Under CRDP, Chapter 7, 14.

Dewan, A.M., Y. Yamaguchi, and M.Z. Rahman. 2010. Dynamics of Land Use/Cover Changes and the Analysis Of Landscape Fragmentation in Dhaka Metropolitan, Bangladesh. GeoJournal 77 (3): 315-330. https://doi.org/10.1007/s1070 8-010-9399-X

Dewan, A.M., M.H. Kabir, K. Nahar, and M.Z. Rahman. 2012. Urbanisation and Environmental Degradation in Dhaka Metropolitan Area of Bangladesh. International Journal of Environment and Sustainable Development 11 (2): 118-147.

Dowall, David E. 1992. Benefits of Minimal Land Use Regulations in Developing Countries. Cato Journal 12 (2): $413-423$.

Einsweiler, Robert C. 1995. 'Impact of Land Use Regulation and Taxation on Property Values', Landlines (newsletter). Lincoln Institute of Land Policy, Mass 7 (2): 3.

Gafur S. 2008. A Review on Dhaka's Urban Land Market. http://tutor2u.net/economics/content/topics/housing/housi ng_demand_supply.htm. Accessed 11 Oct 2008.

Green, D.M., and M.G. Baker. 2003. Urbanization Impacts on Habitat and Bird Communities in a Sonoran Desert Ecosystem. Landscape and Urban Planning 63 (4): 21-37.

Grimm, N.B., S.H. Faeth, N.E. Golubiewski, C.L. Redman, J. Wu, X. Bai, and J.M. Briggs. 2008. Global Change and the Ecology of Cities. Science 319 (5864): 756-760.

Herold, M., K.C. Clarke, and J. Scepan. 2002. The Use of Remote Sensing and Landscape Metrics to Describe Structures and Changes in Urban Land Use. Environmental Planning A 34 (8): 1443-1458.

Islam, N. 2001. Managing the future of Dhaka. In Urbanization, Urban Planning and Development and Urban Governance, vol. 2005, 1st ed, ed. N. Islam, 141-155. Dhaka: Centre for Urban Studies.

Kamal, A.S.M.M., and S. Midorikawa. 2004. GIS-based Geomorphological Mapping Using Remote Sensing Data and Supplementary Geoinformation a Case Study of the Dhaka City Area, Bangladesh. International Journal of Applied Earth Observation and Geoinformation 6 (2): 111-125.

Khatun, H., and M. Hoque. 1994. Role of Hazaribagh Leather Industry in Environmental Pollution. Geography Journal 13 (1): 179-189.

Knox, C. 2009. Dealing With Sectoral Corruption in Bangladesh: Developing Citizen Involvement. Public Administration and Development 29 (2): 117-132. 
Koonings, K., and D. Kruijt (eds.). 2009. Megacities: the Politics of Urban Exclusion and Violence in the Global South. London: Zed Books.

Liu, J., G.C. Daily, P.R. Ehrlich, and G.W. Luck. 2003. Effects of Household Dynamics on Resource Consumption and Biodiversity. Nature 421: 530-533.

Lopez, E., G. Bocco, M. Mendoza, and E. Duhau. 2001. Predicting Land Cover and Land Use Change in the Urban Fringe a Case in Morelia City, Mexico. Landscape and Urban Planning 55 (4): 271-285.

Makathy, T. 2008. Policy Adjustment for Managing Unplanned Land Sub-division Development in an Immature Planning, Phnom Penh, Cambodia. Ph.D. Dissertation, Department of Urban Engineering, Graduate School of Engineering, The University of Tokyo Japan, Chapter 3, 2-23.

Mandal, M. 2000. Urban Geography: a Textbook. New Delhi: Concept Publishing Company.

Mayo, S. K. 1998. Land Prices, Land Markets, and the Broader Economy, Land Lines: 10(2). http://www.lincolninst.edu/ pubs/427_Land-Prices--Land-Markets--and-the-Broader-Economy. Accessed 12 Sept 2010.

McAuslan, P. 1999. Housing Tenure, the Urban Poor and the Law in Bangladesh: Implementing the Habitat Agenda, Paper Presented in the Seminar on Secure Tenure: Access to Urban Land and Urban Housing Finance in Bangladesh, Dhaka, 17-18 November 1999. In: Edited (2000) Urban Land Tenure and Urban Housing Finance in Bangladesh, ed. Islam N, 38-115. CUS, Dhaka for UNCHS (Habitat).

McDonnell, M.J., S. Pickett, P. Groffman, and P. Bohlen. 1997. Ecosystem Processes Along an Urban-to-Rural Gradient. Urban Ecosystem 1 (1): 21-36.

McKinney, M.L. 2006. Urbanization as a Major Cause of Biotic Homogenization. Biological Conservation 127 (3): 247-260.

Nagendra, H., D.K. Munroe, and J. Southworth. 2004. From Pattern and Process: Landscape Fragmentation and the Analysis of Land Use/Cover Change. Agriculture, Ecosystem and Environment 101 (2-3): 111-115.

Panday, P.K. 2007. Policy Implementation in Urban Bangladesh: Role Of Intra-Organizational Coordination. Public Organization Review 7 (3): 237-259.

Rahaman, M.M. 2008. Parliament and Good Governance: a Bangladeshi Perspective. Japanese Journal of Political Science 9 (1): 39-62.

Rahman, T. and Khan, N. A. 2008. Rethinking Corruption, New Age, a Vernacular English Daily. http://www.newagebd. com. Accessed 9 July.

REHAB. 2014. Real Este Housing Association Bangladesh.

Sen, B. 2015. 'Bangladesh's Middle-Class Expanding', The Daily Star, 06 Nov 2015, a Bangladeshi Daily Newspaper's Report on Bangladesh Institute of Development Studies (BIDS) Study. Accessed 25 Mar 2018.

Seraj, T. M. 2007. Future of the Private Real Estate Industry and its Actions Needed Paper Presented in the Hotel West Inn Dhaka, on the Occasion of REHAB Fair 2007, November 19, 2-3.

The New Age. 2017. A National Daily Newspaper, 17 May.

The Daily ProthomAlo. 2008. A Bangladeshi Daily Newspaper, 2 July.

The Daily Prothom Alo. 2016a. A Bangladeshi Daily Newspaper, 15 November.

The Daily Prothom Alo. 2016b. A Bangladeshi Daily Newspaper, 12 November.

The Daily Sangbad. 2009. A National Daily Newspaper. May 30.

The Daily Sangram. 2008. A Bangladeshi Daily Newspaper 5 July.

UN. 2002. World Urbanization Prospects: the 2001 Revision. New York: Department of Economic and Social Affairs, Population Division, United Nations.

UN-HABITAT. 2008/2009. State of the World Cities, Harmonious Cities. Nairobi: UN-HABITAT, 6-152.

Weng, Q. 2001. Modeling Urban Growth Effects on Surface Runoff with the Integration of Remote Sensing and GIS. Environmental Management 28 (6): 737-748.

Wenzel, F. F. Bendimerad, and R. Sinha. 2007. Megacities-Megarisks. Natural Hazards 42 (3): 481-491.

World Bank. 2007. The World Bank Bangladesh Development Series, 106. Washington, D.C.: World Bank.

Xian, G., M. Crane, and J. Su. 2007. An Analysis of Urban Development and its Environmental Impact on the Tampa Bay Watershed. Journal of Environmental Management 85 (4): 965-976.

\section{Submit your manuscript to a SpringerOpen ${ }^{\circ}$ journal and benefit from:}

- Convenient online submission

- Rigorous peer review

- Open access: articles freely available online

High visibility within the field

- Retaining the copyright to your article

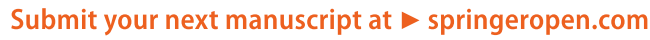

